University of Nebraska - Lincoln

DigitalCommons@University of Nebraska - Lincoln

\title{
Synthesis and Antimalarial Activity of New Isotebuquine Analogues
}

Olga V. Miroshnikova

DiVision of Experimental Therapeutics, Walter Reed Army Institute of Research, 503 Robert Grant AVenue, SilVer Spring, Maryland

Thomas H. Hudson

DiVision of Experimental Therapeutics, Walter Reed Army Institute of Research, 503 Robert Grant AVenue, SilVer Spring, Maryland

Lucia Gerena

DiVision of Experimental Therapeutics, Walter Reed Army Institute of Research, 503 Robert Grant AVenue, SilVer Spring, Maryland

Dennis E. Kyle

DiVision of Experimental Therapeutics, Walter Reed Army Institute of Research, 503 Robert Grant AVenue, SilVer Spring, Maryland

Ai J. Lin

DiVision of Experimental Therapeutics, Walter Reed Army Institute of Research, 503 Robert Grant AVenue, SilVer Spring, Maryland

Follow this and additional works at: https://digitalcommons.unl.edu/usarmyresearch

Part of the Operations Research, Systems Engineering and Industrial Engineering Commons

Miroshnikova, Olga V.; Hudson, Thomas H.; Gerena, Lucia; Kyle, Dennis E.; and Lin, Ai J., "Synthesis and Antimalarial Activity of New Isotebuquine Analogues" (2007). US Army Research. 43.

https://digitalcommons.unl.edu/usarmyresearch/43

This Article is brought to you for free and open access by the U.S. Department of Defense at DigitalCommons@University of Nebraska - Lincoln. It has been accepted for inclusion in US Army Research by an authorized administrator of DigitalCommons@University of Nebraska - Lincoln. 


\title{
Synthesis and Antimalarial Activity of New Isotebuquine Analogues
}

\author{
Olga V. Miroshnikova, Thomas H. Hudson, Lucia Gerena, Dennis E. Kyle, and Ai J. Lin* \\ Division of Experimental Therapeutics, Walter Reed Army Institute of Research, 503 Robert Grant Avenue, Silver Spring, Maryland 20910
}

Received October 20, 2006

Amodiaquine (AQ) and tebuquine are 4-aminoquinoline antimalarials with Mannich base side chain and are highly effective against chloroquine (CQ)-resistant strains of Plasmodium falciparum. Clinical use of AQ has been severely restricted due to hepatoxicity and agranulocytosis side effects associated with its long term use. Lysosomal accumulation and bioactivation to generate reactive quinoneimine metabolite are implicated to be the cause of the observed AQ toxicities. To avoid the quinoneimine formation and thus the toxicity, a series of isotebuquine analogues and their $N^{\omega}$-oxides with hydroxy group meta to the amino rather than in para position of the aniline moiety were prepared. The new Mannich bases are highly active against both CQ-sensitive (D6) and -resistant (W2 and TM91C235) clones of $P$. falciparum with $\mathrm{IC}_{50}$ in the range of $0.3-120 \mathrm{ng} / \mathrm{mL}$. New compounds are 1000-fold less toxic $\left(\mathrm{IC}_{50}=0.7-6 \mu \mathrm{g} / \mathrm{mL}\right)$ to mouse macrophage cell line than to parasite cell lines. Mono-Mannich bases are more active than bis-Mannich bases. Mono-Mannich base 1a $\left(\mathrm{IC}_{50}=0.3 \mathrm{ng} / \mathrm{mL}\right)$ is 20 -fold more active than the corresponding trifluoromethyl analogue $\mathbf{1 b}$. No appreciable difference in either toxicity or efficacy were observed between the new Mannich bases ( $m$-hydroxyaniline derivatives) 1a or 2a and the corresponding $p$-hydroxyaniline derivatives.

\section{Introduction}

Malaria is one of the most widespread diseases in many regions of the world, exposing millions of people to risk of infection and death. The 4-aminoquinolines such as chloroquine (CQ) are the most important and widely used class of drugs for treatment of malaria. Chloroquine has been the drug of choice for malaria treatment since the early 1950s, providing effective and safe treatment for millions of Plasmodium falciparum infected patients a year. Development of drug resistance to chloroquine in malaria has become a major health concern in malaria endemic areas, which has prompted a search for alternative antimalarials against the CQ-resistant strains. ${ }^{1,2}$ As a result, several new classes of antimalarial drugs were developed; none has reached the same status of recognition as the drug of choice in malaria therapy as CQ.

Amodiaquine (AQ), a new Mannich base 4-aminoquinoline, is effective against chloroquine-resistant strains of $P$. falciparum. ${ }^{3}$ However, the clinical use of AQ has been severely restricted because of the hepatoxicity and agranulocytosis side effects associated with its long term use. ${ }^{4,5}$ Recent reports indicate that AQ was metabolized by cytochrome P-450 oxidation to form reactive quinoneimine metabolite with subsequent conjugate addition of glutathione or cysteinyl function of the enzymes. ${ }^{6,7}$ Lysosomal accumulation and bioactivation of reactive quinoneimine metabolite are implicated to be the cause of the observed AQ in vivo toxicity. ${ }^{8,9}$ To avoid the quinoneimine metabolite formation, a series of isoquine and related analogues were reported in the literature. ${ }^{10-12}$ Isoquine (IQ) is an analogue of AQ, in which the $4^{\prime}$-hydroxy group on the aniline ring of AQ is interchanged with a $3^{\prime}$-Mannich base side chain. IQ was demonstrated to possess higher antimalarial activity against Plasmodium yoelii than AQ. In contrast to AQ, IQ was excreted primarily as glucuronide, instead of glutathione conjugate. ${ }^{10}$

Another promising compound from the class of the 4-aminoquinolines is tebuquine (TQ), which is a biaryl analogue of AQ

* To whom correspondence should be addressed. Phone: 301-319-9084. Fax: 301-319-9449. E-mail: ai.lin@na.amedd.army.mil.<smiles>CN(C)Cc1cc(Nc2ccnc3cc(Cl)ccc23)ccc1O</smiles><smiles>CN(C)Cc1ccc(Nc2ccnc3cc(Cl)ccc23)cc1O</smiles><smiles>CC(C)(C)NCc1cc(Nc2ccnc3cc(Cl)ccc23)cc(-c2ccc(I)cc2)c1O</smiles>

Isoquine

Tebuquine

with a $p$-chlorophenyl moiety substituted at the 5-position of the 4-hydroxyaniline side chain of AQ. TQ is significantly more active than AQ and CQ in both in vitro and in vivo tests. ${ }^{13-15}$ Similar to AQ, TQ forms active quinoneimine metabolite (Scheme 1) and consequently develops the same toxic side effects as AQ in prolonged use.

In this study, we described the synthesis of a series of isotebuquine analogues with a hydroxy group in meta rather than para position to the amino group of the aniline moiety. Unable to produce the toxic quinoneimine metabolite, new isotebuquine analogues may exhibit similar or better activity than tebuquine with no or low liver toxicity. In vitro antimalarial activities of the new compounds were assessed in CQ-sensitive (D6) and CQ-resistant (W2) cell lines of P. falciparum, and their in vitro toxicities were measured in a murine monocytelike macrophage line J774. Furthermore, in vivo antimalarial efficacy values against Plasmodium berghei of the new compounds are presented.

\section{Chemistry}

The initial step of this work was the synthesis of bis- and mono-(tert-butylaminomethyl)-5-(7-chloroquinolin-4-ylamino)- 
Scheme 1. Biotransformation of Tebuquine by P-450 Oxidation and Further Conjugation with Cysteinyl Function of Enzymes

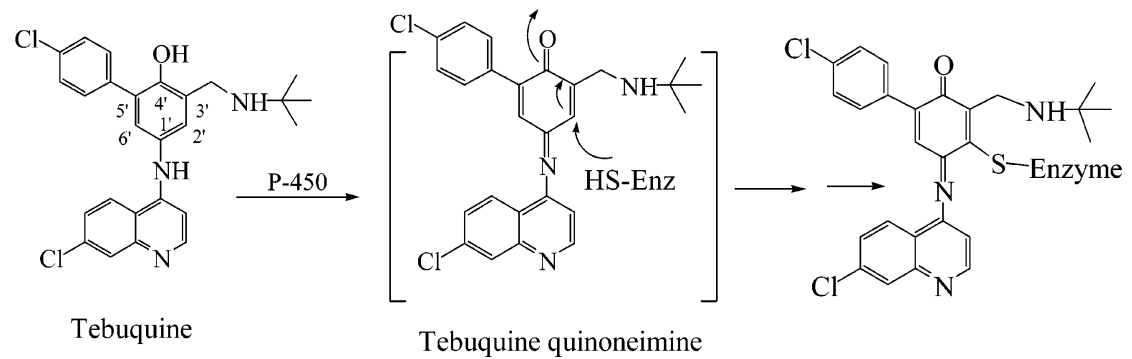

Scheme $2^{a}$

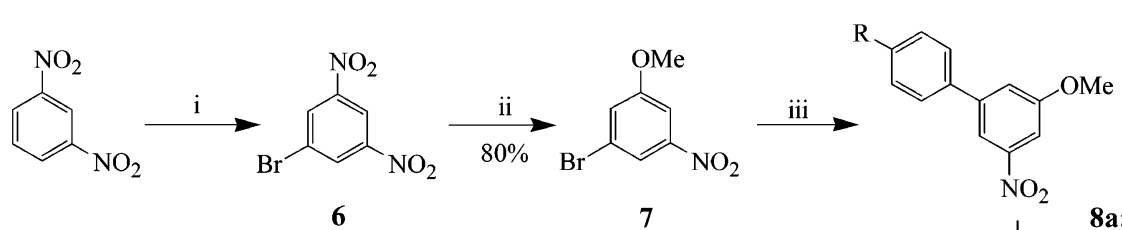

6

8a: $\mathrm{R}=\mathrm{C}$<smiles>[R]c1ccc(-c2cc(O)cc(Nc3ccnc4cc(Cl)ccc34)c2)cc1-c1ccc(CCCCC)cc1</smiles><smiles>[R]c1ccc(-c2cc(O)cc(Nc3ccnc4cc(Cl)ccc34)c2CNC(C)(C)C)cc1</smiles>

1a, b

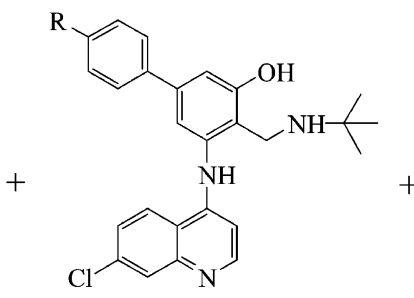

2a, b

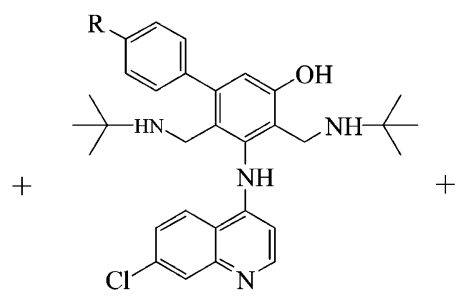

3a, b<smiles>[R]c1ccc(-c2c(CNC(C)(C)C)c(O)cc(Nc3ccnc4cc(Cl)ccc34)c2CNC(C)(C)C)cc1</smiles>

4a, b<smiles>[R]c1ccc(-c2cc(Nc3ccnc4cc(Cl)ccc34)cc(O)c2CNC(C)(C)C)cc1</smiles>

$5 a, b$

${ }^{a}$ Reagents and conditions: (i) $\mathrm{N}$-bromosuccinimide, $\mathrm{H}_{2} \mathrm{SO}_{4}, 80^{\circ} \mathrm{C}$; (ii) $\mathrm{NaOMe}, \mathrm{MeOH}, 65^{\circ} \mathrm{C}, 2 \mathrm{~h}$; (iii) $\mathrm{RPhB}(\mathrm{OH})_{2}, \mathrm{Pd}\left(\mathrm{PPh}_{3}\right)_{4}, \mathrm{Na}_{2} \mathrm{CO}_{3}$, toluene, EtOH, reflux, $2 \mathrm{~h}$; (iv) $\mathrm{H}_{2}, 10 \% \mathrm{Pd} / \mathrm{C}$, THF, $2 \mathrm{~h}$; (v) $\mathrm{BBr}_{3}, \mathrm{CH}_{2} \mathrm{Cl}_{2},-78^{\circ} \mathrm{C}$, $4 \mathrm{~h}$; (vi) 4,7-dichloroquinoline, EtOH, reflux, $2 \mathrm{~h}$; (vii) $t$ - $\mathrm{BuNH}_{2}, \mathrm{CH}_{2} \mathrm{O}, \mathrm{DMF}, 3$ days.

biphenyl-3-ols, the so-called isotebuquine analogues. The general approach to prepare the new Mannich bases $\mathbf{1 a}, \mathbf{b}-\mathbf{5 a}, \mathbf{b}$ is illustrated in Scheme 2. The intermediate 1-bromo-3,5dinitrobenzene (6) was prepared by addition of the $\mathrm{N}$-bromosuccinimide in small portions to the commercially available starting material 1,3-dinitrobenzene in sulfuric acid at $80-90$ ${ }^{\circ} \mathrm{C} .{ }^{16}$

3-Bromo-5-nitroanisole (7) was obtained by treatment of 6 with sodium methoxide in absolute methanol. ${ }^{17}$ The coupling of bromoanisole 7 with the 4-chlorophenylboronic acid was achieved using a modified Suzuki method to afford substituted biaryl compound $\mathbf{8 a}$ in a good yield. ${ }^{18}$ Two types of catalysts were used in the Suzuki coupling reaction to prepare compounds $\mathbf{8 a}$ and $\mathbf{8 b}$. Method A utilized tetrakis-(triphenylphosphine) palladium(0), ${ }^{18}$ while method $\mathrm{B}$ employed $\mathrm{Pd}(\mathrm{OAc})_{2}$ as a catalyst (Scheme 3). ${ }^{19}$ The compound 8a was prepared by method A, while trifluoromethyl analogue $\mathbf{8 b}$ was synthesized by method B. Both coupling methods A and B were efficient to prepare the biaryl intermediates when 3,5-dinitro-bromobenzene was used. However, when the 1-iodo-3,5-dinitrobenzene 
Scheme $3^{a}$<smiles>CC(C)CCCC(C)C</smiles><smiles>COc1cc(Br)cc([N+](=O)[O-])c1</smiles>

${ }^{a}$ Reagents and conditions: (i) 4-chlorophenylboronic acid or 4-(trifluoromethyl)phenylboronic acid, $\mathrm{Pd}\left(\mathrm{PPh}_{3}\right)_{4}, \mathrm{Na}_{2} \mathrm{CO}_{3}$, toluene, EtOH, reflux, $2 \mathrm{~h}$; (ii) 4-(trifluoromethyl)phenylboronic acid, $\mathrm{Pd}(\mathrm{OAc})_{2}, \mathrm{~K}_{2} \mathrm{CO}_{3}$, acetone, $\mathrm{H}_{2} \mathrm{O}$, reflux, $4 \mathrm{~h}$; (iii) $\mathrm{NaOMe}, \mathrm{MeOH}, \mathrm{DMF}, 65^{\circ} \mathrm{C}, 2 \mathrm{~h}$.

was used as a starting material in the Suzuki coupling reaction, it gave a poorer yield than when 1-bromo-3,5-dinitrobenzene was used, due to incomplete reaction and tedious purification procedure.

The reduction of the nitro-group by catalytic hydrogenation of $\mathbf{8}$ using palladium on activated carbon afforded the aminobiphenyl derivatives 9 in a quantitative yield. ${ }^{20}$ The intermediate amines obtained were used for the next reaction without further purification. The boron tribromide-catalyzed demethylation of 9a in dichloromethane solution gave a desired aminophenol 10a in high yield $(70 \%)$. The trifluoromethyl-containing analogue 10b was obtained using an alternative reagent, boron tribromide-methylsulfide complex. ${ }^{21}$

The intermediates 11a and 11b for the synthesis of isotebuqine analogues were obtained by treatment of 4,7-dichloroquinoline with corresponding biarylaminophenols 11a,b. Introduction of the Mannich base side chain, tert-butylaminomethyl, into the key intermediate $\mathbf{1 1}$ was a challenging task due to low selectivity of the reaction. When $\mathbf{1 1 a}$ or $\mathbf{1 1 b}$ was subjected to Mannich reaction in the presence of $t$-butylamine and $37 \%$ formaldehyde, a mixture consisting of five products was obtained. The mixture was separated by the use of a silica gel column followed by fractional crystallization. The product ratio of this reaction was highly dependent on the ratio of the reagents used. Formation of bis-Mannich base $\mathbf{3}$ was favored when the reaction was conducted using a stoichiometric amount of reagents, 11, $t$-buthylamine, and formaldehyde. Doubling the ratio of the reagents, $t$-buthylamine and formaldehyde, led to the formation of both mono-Mannich base $\mathbf{1}$ as well as bisMannich base 3. Further addition of reagents to the same reaction mixture gave other analogues, 2 (mono-) and 4 (bis-), in small yield $(7-10 \%)$. The yield of compound $\mathbf{5}$ was insignificant, isolation of which was possible only in large-scale synthesis. The products were first separated by column chromatography, followed by repeated recrystalization from chloroform and diethyl ether mixture. Purification of products $\mathbf{1}$ and 4 could not be accomplished by chromatography because of their similarity in $R_{f}$ values on TLC under various solvent systems. However, separation of the products was achieved by fractional crystallization from methanol.

The structures of all products were characterized by elemental analysis, mass spectrometry, and ${ }^{1} \mathrm{H}$ and ${ }^{13} \mathrm{C}$ NMR spectroscopy.

As an extension of this work, two $N^{\omega}$-oxide isotebuquine analogues (13 and $\mathbf{1 4}$ ) were prepared to improve solubility and therefore enhance the bioavailability of this type of antimalarials. Synthetic pathway for $N^{\omega}$-oxides was based on the method developed for the synthesis of isotebuquine derivatives (Scheme 4). Thus, $p$-chloro-biarylaminophenol 10a was treated with 4,7dichloroquinoline 1 -oxide ${ }^{13}$ to provide corresponding $4^{\prime}$-chloro5-(7-chloro-1-oxy-quinolin-4-ylamino)-biphenyl-3-ol (12) as outlined in Scheme 4. Contrary to the synthesis of Mannich base $\mathbf{1 - 5}$, which was rather straightforward, the final step in the synthesis of the target $N^{\omega}$-oxide $\mathbf{1 3}$ and $\mathbf{1 4}$ was a challenging task. In an attempt to apply the same conditions for the Mannich reaction that has been utilized for the synthesis of regular isotebuquine analogues $\mathbf{1}-\mathbf{5}$ ( 3 equiv of tert-butylamine, 4 equiv of formaldehyde, DMF, room temperature, 3 days), no reaction was observed. Heating at $100{ }^{\circ} \mathrm{C}$ gave a complicated mixture of high lipophilic byproducts. When the Mannich reaction was carried out in diluted DMF solution $(15 \mathrm{mg} / \mathrm{mL})$ at $65^{\circ} \mathrm{C}$ for 7 days, two new $N^{\omega}$-oxide derivatives, mono- (13) and bisMannich base (14), were obtained in low yield. On scale-up synthesis, two deoxygenated byproducts, 1a and 3a, were isolated.

\section{${ }^{1} \mathrm{H}$ NMR Studies}

Due to poor solubility of some of the final products in $\mathrm{CDCl}_{3}$, most of the NMR spectra were taken in $\mathrm{CD}_{3} \mathrm{OD}$. When compounds are soluble in both chloroform and methanol, the spectrum in both solvents, $\mathrm{CDCl}_{3}$ and $\mathrm{CD}_{3} \mathrm{OD}$, are reported. The structure assignments of $\mathbf{1 - 5}$ were based on comparison of their chemical shifts with the key intermediate 11. The assignment of all protons in compound $\mathbf{1 1}$ is straightforward (Table 1). The ${ }^{1} \mathrm{H}$ NMR spectrum of $\mathbf{1 1 b}$ shows three triplets for protons $\mathrm{Hh}, \mathrm{Hi}$, and $\mathrm{Hj}$ of the aminophenol moiety at 6.91 , 6.96, and $7.15 \mathrm{ppm}$, respectively, with small coupling constant of $J=1.6 \mathrm{~Hz}$. Two sets of doublets at 7.10 and $8.33 \mathrm{ppm}$ were attributed to $\mathrm{Hb}$ and $\mathrm{He}$ of the quinoline ring, and the doublets at 7.75 and $7.82 \mathrm{ppm}$ were assigned to biaryl protons $\mathrm{Hg}$ and Hf, respectively. The proton chemical shifts of intermediate $\mathbf{1 1}$ are informative for the structure determination of its Mannich

\section{Scheme $4^{a}$}
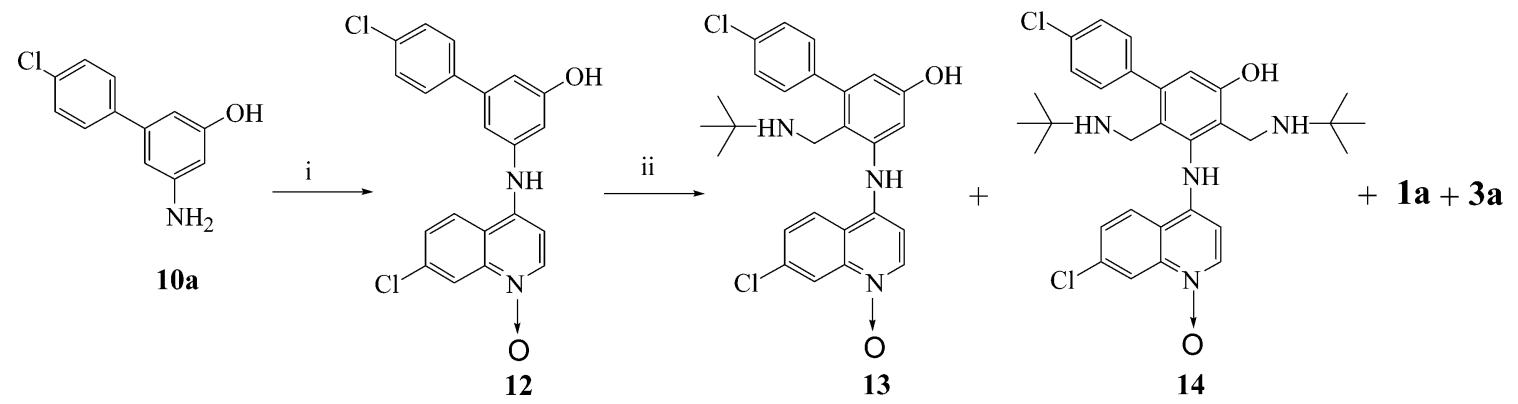

${ }^{a}$ Reagents and conditions: (i) 4,7-dichloroquinoline $N$-oxide, EtOH, reflux, 2 h; (ii) $t$ - $\mathrm{BuNH}_{2}, \mathrm{CH}_{2} \mathrm{O}, \mathrm{DMF}, 8$ days. 
Table 1. ${ }^{1} \mathrm{H}$ NMR Chemical Shifts $(\delta)$ for Aromatic Protons of Isotebuqiune Derivatives $(\mathbf{1 1}$ and $\mathbf{1 - 5 b})$ and Their $N^{\omega}$-Oxides $(\mathbf{1 2}-\mathbf{1 4})$ in $\mathrm{CD}_{3} \mathrm{OD}$ Solution

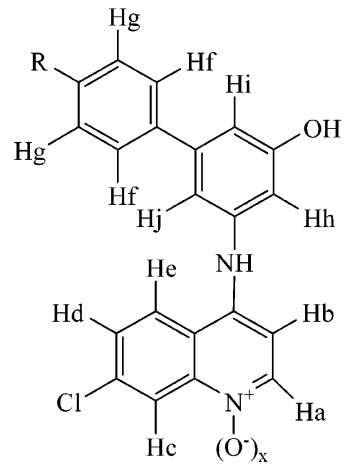

\begin{tabular}{lcccccccccc}
\hline compd & $\mathrm{Ha}$ & $\mathrm{Hb}$ & $\mathrm{Hc}$ & $\mathrm{Hd}$ & $\mathrm{He}$ & $\mathrm{Hf}$ & $\mathrm{Hg}$ & $\mathrm{Hh}$ & $\mathrm{Hi}$ & $\mathrm{Hj}$ \\
\hline $\mathbf{1 1 a}$ & 8.42 & 7.07 & 7.87 & 7.51 & 8.31 & 7.59 & 7.43 & 6.84 & 7.07 & 6.88 \\
$\mathbf{1 a}$ & 8.38 & 7.07 & 7.85 & 7.49 & 8.27 & 7.46 & 7.37 & 6.59 & 6.77 & $\mathrm{MB}^{a}$ \\
$\mathbf{2 a}$ & 8.38 & 6.52 & 7.90 & 7.55 & 8.33 & 7.59 & 7.43 & $\mathrm{MB}$ & 7.03 & 7.00 \\
$\mathbf{3 a}$ & 8.34 & 6.68 & 7.87 & 7.53 & 8.28 & 7.47 & 7.36 & $\mathrm{MB}$ & 6.63 & $\mathrm{MB}$ \\
4a & 8.42 & 6.98 & 7.88 & 7.51 & 8.28 & 7.51 & 7.33 & 6.93 & $\mathrm{MB}$ & $\mathrm{MB}$ \\
$\mathbf{1 1 b}$ & 8.44 & 7.10 & 7.90 & 7.53 & 8.33 & 7.82 & 7.75 & 6.91 & 7.15 & 6.96 \\
$\mathbf{1 b}$ & 8.39 & 7.08 & 7.86 & 7.49 & 8.28 & 7.76 & 7.58 & 6.61 & 6.80 & $\mathrm{MB}$ \\
$\mathbf{2 b}$ & 8.38 & 6.53 & 7.89 & 7.55 & 8.33 & 7.80 & 7.72 & $\mathrm{MB}$ & 7.08 & 7.05 \\
$\mathbf{3 b}$ & 8.34 & 6.61 & 7.86 & 7.52 & 8.27 & 7.73 & 7.57 & $\mathrm{MB}$ & 6.67 & $\mathrm{MB}$ \\
$\mathbf{4 b}$ & 8.43 & 6.99 & 7.89 & 7.52 & 8.23 & 7.52 & 7.33 & 6.93 & $\mathrm{MB}$ & $\mathrm{MB}$ \\
$\mathbf{5 b}$ & 8.61 & 7.32 & 8.05 & 7.44 & 7.93 & 7.73 & 7.47 & 6.64 & $\mathrm{MB}$ & 6.99 \\
$\mathbf{1 2}$ & 8.59 & 7.00 & 8.40 & 7.88 & 8.61 & 7.64 & 7.48 & 6.88 & 7.18 & 7.11 \\
$\mathbf{1 3}$ & 8.35 & 6.56 & 8.62 & 7.78 & 8.47 & 7.59 & 7.42 & 7.01 & 7.03 & $\mathrm{MB}$ \\
$\mathbf{1 4}$ & 8.33 & 6.49 & 8.60 & 7.76 & 8.57 & 7.46 & 7.34 & $\mathrm{MB}$ & 6.54 & $\mathrm{MB}$ \\
\hline
\end{tabular}

${ }^{a} \mathrm{MB}=$ Mannich base side chain

base 1-5. Introduction of one or two $t$-butyl-aminomethyl substituents into the aminophenol ring of compound $\mathbf{1 1}$ caused dramatic changes in chemical shifts of the surrounding protons. Distal from Mannich base side chain, proton signals of 7-chloroquinoline moiety, Hd (7.53 ppm), Hc (7.90 ppm), and $\mathrm{Ha}$ $(8.44 \mathrm{ppm})$ were not affected by the introduction of Mannich base. The chemical shifts of aromatic protons of all new isotebuquine derivatives are listed in Table 1.

The structural assignment for compounds 12-14 was made using the same approach for the assignment of deoxy analogues 1-5. Compounds 12-14 share the same basic structure with 1-5, thus their NMR spectra are, as expected, similar for the most part (Table 1).

\section{Experimental Section}

Melting points were determined in open capillary tubes on a Mettler FP62 melting point apparatus (Mettler Toledo, USA) and are uncorrected. ${ }^{1} \mathrm{H}$ NMR and ${ }^{13} \mathrm{C}$ NMR spectra were recorded using a Bruker Avance-300 spectrometer (Bruker Instrument, Inc., Wilmington, DE) at a frequency of $300.13 \mathrm{MHz}$. Chemical shifts are given in $\mathrm{ppm}(\delta)$ relative to tetramethylsilane (TMS) as internal standard. Analytical thin-layer chromatography (TLC) was performed using HPLC-HLF normal phase 150 micrometer silica gel plates or silica gel GF/ UF254, 500 micrometer plates (Analtech, Newark, DE). Visualization of the developed chromatogram was performed with UV absorbance or iodine stain. Flash chromatography was conducted with silica gel $60 \AA$ (200-400) mesh from Sigma-Aldrich Co. Solvents and reagents obtained from commercial sources were used without purification, unless noted. Reactions were carried out under an inert atmosphere of nitrogen. Elemental analysis was performed by Atlantic Microlab, Inc. (Norcross, GA). Where analyses are indicated by symbols of the elements, the analytical results obtained were within $\pm 0.4 \%$ of the theoretical values.

1-Bromo-3,5-dinitrobenzene (6). ${ }^{16}$ 1,3-Dinitrobenzene (10 g, $59.5 \mathrm{mmol})$ was dissolved in concentrated sulfuric acid $(60 \mathrm{~mL})$ at $80{ }^{\circ} \mathrm{C}$. $\mathrm{N}$-Bromosuccinimide $(14.83 \mathrm{~g}, 83.3 \mathrm{mmol})$ was added to the reaction mixture in nine portions over $1.5 \mathrm{~h}$ (one addition every $10 \mathrm{~min}$ ). The temperature of the mixture was kept at $80-90{ }^{\circ} \mathrm{C}$ during the addition. After the reaction was completed (30 min), the sulfuric acid solution was poured into ice water. The solid precipitate was collected, washed with water, and recrystalized from methanol to give $12.2 \mathrm{~g}(83 \%)$ of the desired product 6 as a pale yellow crystal, mp 77.2-77.8 ${ }^{\circ} \mathrm{C}$ (lit., $77-78{ }^{\circ} \mathrm{C}$ ). ${ }^{1} \mathrm{H}$ NMR $\left(\mathrm{CDCl}_{3}\right): \delta 9.03(\mathrm{t}, J=2.0 \mathrm{~Hz}, 1 \mathrm{H}), 8.73(\mathrm{~d}, J=2.0 \mathrm{~Hz}, 2 \mathrm{H}),{ }^{13} \mathrm{C}$ NMR: $148.85,132.10,123.88,117.72$. Anal. $\left(\mathrm{C}_{6} \mathrm{H}_{3} \mathrm{BrN}_{2} \mathrm{O}_{4}\right) \mathrm{C}, \mathrm{H}$, N.

1-Bromo-3-methoxy-5-nitrobenzene (7). ${ }^{17}$ To the solution of compound $6(12 \mathrm{~g}, 48.6 \mathrm{mmol})$ in dry methanol $(120 \mathrm{~mL})$ was added sodium methoxide ( $3.24 \mathrm{~g}, 60 \mathrm{mmol})$. The mixture was boiled for $2 \mathrm{~h}$ and allowed to cool to room temperature. The reaction was quenched by additional of $1 \mathrm{~N}$ solution of $\mathrm{HCl}$, and the mixture was extracted with dichloromethane $(2 \times 250 \mathrm{~mL})$. Organic layers were combined, washed with brine, dried over sodium sulfate, filtered, and evaporated to dryness in vacuum. The crude product was purified by flash column chromatography on silica gel, eluting with a gradient of $2 \%$ ethyl acetate in hexane followed by $10-$ $12 \%$ ethyl acetate in hexane to yield $9.25 \mathrm{~g}(82 \%)$ of 7 as a white solid, mp $86.9^{\circ} \mathrm{C}$ (lit., $\left.87.5^{\circ} \mathrm{C}\right) .{ }^{17}{ }^{1} \mathrm{H} \mathrm{NMR}\left(\mathrm{CDCl}_{3}\right): \delta 7.99(\mathrm{t}, J$ $=1.83 \mathrm{~Hz}, 1 \mathrm{H}), 7.70(\mathrm{t}, J=2.2 \mathrm{~Hz}, 1 \mathrm{H}), 7.40(\mathrm{t}, J=2.2 \mathrm{~Hz}, 1 \mathrm{H})$, 3.92 (s, 3H). ${ }^{13} \mathrm{C}$ NMR: $160.62,149.50,123.92,123.01,118.98$, 107.78 , and 56.20 .

4'-Chloro-5-methoxy-3-nitro-biphenyl (8a). Method A. Compound $7(6.93 \mathrm{~g}, 30 \mathrm{mmol})$ and sodium carbonate $(30 \mathrm{~mL}$ of $2 \mathrm{M}$ solution) were suspended in a mixture of toluene and ethanol (120 $\mathrm{mL}, 4: 1$ ). To the bilayer mixture were sequentially added 4-chlorophenylboronic acid $(5.16 \mathrm{~g}, 33 \mathrm{mmol})$ and tetrakis(triphenylphosphine) palladium $(0)$ with stirring. The reaction mixture was refluxed for $2 \mathrm{~h}$ under nitrogen atmosphere. On cooling to room temperature, the solution was poured onto ice water. Solid precipitate formed was collected, dried, and purified by flash column chromatography on silica gel eluting with a gradient of $1 \%$ ethyl acetate in hexane followed by $10 \%$ ethyl acetate in hexane to give $6.33 \mathrm{~g}(80 \%)$ of product 8a as a pale yellow solid, mp $131.7{ }^{\circ} \mathrm{C}$. ${ }^{1} \mathrm{H}$ NMR $\left(\mathrm{CDCl}_{3}\right): \delta 8.04(\mathrm{t}, J=1.7 \mathrm{~Hz}, 1 \mathrm{H}), 7.74(\mathrm{t}, J=2.1 \mathrm{~Hz}, 1 \mathrm{H})$, $7.56(\mathrm{~d}, J=8.6 \mathrm{~Hz}, 2 \mathrm{H}), 7.47(\mathrm{~d}, J=8.6 \mathrm{~Hz}, 2 \mathrm{H}), 7.41(\mathrm{t}, J=1.7$ $\mathrm{Hz}, 1 \mathrm{H}), 3.97$ (s, 3H). ${ }^{13} \mathrm{C}$ NMR: $160.53,149.73,142.44,137.17$, $134.89,129.33,128.41,119.72,114.41,106.85,56.04 . \mathrm{MS}(\mathrm{m} / \mathrm{z})$ : $264.11\left(\mathrm{MH}^{+}\right)$.

5-Methoxy-3-nitro-4'-trifluoromethyl-biphenyl (8b). Method B. To the solution of compound $6(2.7 \mathrm{~g}, 11.64 \mathrm{mmol})$ and 4-(trifluoromethyl)phenylboronic acid $(2.43 \mathrm{~g}, 12.80 \mathrm{mmol})$ in the mixture of acetone and water $(57 \mathrm{~mL}, 27: 30)$ were added potassium carbonate $(4.0 \mathrm{~g}, 29.0 \mathrm{mmol})$ and palladium(II) acetate $(100 \mathrm{mg})$. The deep black mixture was refluxed for $4 \mathrm{~h}$ and allowed to cool to room temperature. The mixture was extracted with ethyl acetate $(2 \times 150 \mathrm{~mL})$, and the organic layer was passed through a layer of Celite. The solution was dried by $\mathrm{Na}_{2} \mathrm{SO}_{4}$ and evaporated in vacuum to dryness. The residue was purified by flash column chromatography on silica gel eluting with a gradient of $2 \%$ ethyl acetate in hexane followed by $10 \%$ ethyl acetate in hexane to give $3.2 \mathrm{~g}(92 \%)$ of the desired product as a pale yellow solid, mp 54.6 ${ }^{\circ} \mathrm{C} .{ }^{1} \mathrm{H}$ NMR $\left(\mathrm{CDCl}_{3}\right): \delta 8.08(\mathrm{t}, J=1.6 \mathrm{~Hz}, 1 \mathrm{H}), 7.78(\mathrm{t}, J=2.1 \mathrm{~Hz}, 1 \mathrm{H})$, $7.76(\mathrm{~d}, J=3.0 \mathrm{~Hz}, 4 \mathrm{H}), 7.45(\mathrm{t}, J=1.6 \mathrm{~Hz}, 1 \mathrm{H}), 3.98(\mathrm{~s}, 3 \mathrm{H})$. ${ }^{13}$ C NMR: $160.61,149.73,142.17,130.92,130.48,130.05,129.68$, $129.23,127.56,126.17,126.12,126.07,126.02,125.79,122.19$, 120.05, 118.7, 114.65, 107.40, 56.08. MS (m/z): $298.14\left(\mathrm{MH}^{+}\right)$.

4'-Chloro-5-methoxy-biphenyl-3-ylamine (9a). A solution of $8 \mathbf{a}(6.0 \mathrm{~g}, 22.75 \mathrm{mmol})$ with a catalytic amount of $10 \%$ palladium on activated carbon ( $0.6 \mathrm{~g}, 10 \%$ of the weight) was hydrogenated in tetrahydrofuran under 40 psi pressure at room temperature for 2 h. The black mixture was passed through a thin layer of Celite, and the yellow solution was evaporated in vacuum to give $5.10 \mathrm{~g}$ (96\%) of crude product as a gum, which was pure enough to be used for next step synthesis without further purification. A portion of the mixture was purified to give pure product as a gum. ${ }^{1} \mathrm{H}$ NMR $\left(\mathrm{CDCl}_{3}\right): \delta 7.49(\mathrm{~d}, J=8.6 \mathrm{~Hz}, 2 \mathrm{H}), 7.39(\mathrm{~d}, J=8.6 \mathrm{~Hz}, 2 \mathrm{H})$, $6.51(\mathrm{t}, J=1.7 \mathrm{~Hz}, 1 \mathrm{H}), 6.49(\mathrm{t}, J=1.7 \mathrm{~Hz}, 1 \mathrm{H}), 6.27(\mathrm{t}, J=2.1$ 
Hz, 1H), 3.84 (s, 3H). 3.78 (br s, 2H). ${ }^{13} \mathrm{C}$ NMR: 161.15, 148.05, 142.33, 139.83, 133.36, 128.75, 128.35, 106.70, 103.30, 100.11, 55.28. MS $(\mathrm{m} / \mathrm{z}): 234.13\left(\mathrm{MH}^{+}\right)$.

5-Methoxy-4'-trifluoromethyl-biphenyl-3-ylamine (9b). Compound $9 \mathbf{b}$ was prepared by the same method as described for the preparation of 9a in a quantitative yield. ${ }^{1} \mathrm{H}$ NMR $\left(\mathrm{CDCl}_{3}\right): \delta 7.67$ $(\mathrm{s}, 4 \mathrm{H}), 6.56(\mathrm{t}, J=1.6 \mathrm{~Hz}, 1 \mathrm{H}), 6.52(\mathrm{t}, J=1.6 \mathrm{~Hz}, 1 \mathrm{H}), 31(\mathrm{t}$, $J=2.1 \mathrm{~Hz}, 1 \mathrm{H}) .{ }^{13} \mathrm{C} \mathrm{NMR}: 161.21,148.17,144.93,142.10$, $130.18,130.03,129.60,129.17,127.38,126.12,125.62,125.58$, $125.53,125.48,122.52,118.92,106.89,103.57,100.55,55.28 . \mathrm{MS}$ $(\mathrm{m} / \mathrm{z}): 268.53\left(\mathrm{MH}^{+}\right)$.

5-Amino-4' -chloro-biphenyl-3-ol (10a). To a solution of 9a (5.0 $\mathrm{g}, 21.4 \mathrm{mmol})$ in dry dichloromethane $(60 \mathrm{~mL})$ under a nitrogen atmosphere at $-78{ }^{\circ} \mathrm{C}$ was slowly added a solution of boron tribromide $(1.0 \mathrm{M}, 27 \mathrm{~mL})$ in dry dichloromethane. The reaction mixture was allowed to warm to room temperature and stirred for $4 \mathrm{~h}$. The brown solution was cooled with an ice bath, and to the solution was slowly added water $(100 \mathrm{~mL})$. The organic layer was separated, and the water layer was extracted twice with dichloromethane. The dichloromethane extracts were combined, washed successively with saturated sodium bicarbonate solution and water, dried over $\mathrm{Na}_{2} \mathrm{SO}_{4}$, and evaporated to dryness in vacuum. The residue was purified by flash column chromatography on silica gel eluting with dichloromethane followed by $5 \%$ ethyl acetate in dichloromethane to give $3.29 \mathrm{~g}(70 \%)$ of $\mathbf{1 0 a}$ as a white solid, $\mathrm{mp}$ $242.7{ }^{\circ} \mathrm{C}$ dec. ${ }^{1} \mathrm{H}$ NMR $\left(\mathrm{CD}_{3} \mathrm{OD}\right): \delta 7.51(\mathrm{~d}, J=8.6 \mathrm{~Hz}, 2 \mathrm{H})$, $7.38(\mathrm{~d}, J=8.6 \mathrm{~Hz}, 2 \mathrm{H}), 6.48(\mathrm{t}, J=1.7 \mathrm{~Hz}, 1 \mathrm{H}), 6.39(\mathrm{t}, J=1.7$ $\mathrm{Hz}, 1 \mathrm{H}), 6.23(\mathrm{t}, J=2.0 \mathrm{~Hz}, 1 \mathrm{H}) .{ }^{13} \mathrm{C}$ NMR: $158.30,149.11$, 141.62, 140.27, 132.63, 128.17, 127.89, 105.61, 103.72, 101.53. MS $(\mathrm{m} / \mathrm{z}): 220.16\left(\mathrm{MH}^{+}\right)$.

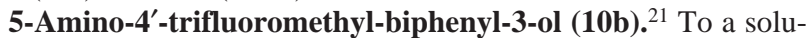
tion of compound $\mathbf{9 b}(2.6 \mathrm{~g}, 9.73 \mathrm{mmol})$ in 1,2-dichloroethane (50 $\mathrm{mL})$ was added boron tribromide methyl sulfide complex $(10.9 \mathrm{~g}$, $34.05 \mathrm{mmol}$ ), and the resulting mixture was refluxed overnight. The reaction was allowed to cool down to room temperature and was quenched with water. The organic phase was washed with saturated sodium bicarbonate solution followed by brine, dried over sodium sulfate, and evaporated in vacuum to dryness. The residue was purified using flash chromatography on silica gel eluting with $10 \%$ ethyl acetate in chloroform followed by $30 \%$ ethyl acetate in chloroform to give $1.87 \mathrm{~g}(76 \%)$ of $\mathbf{1 0 b}$ as an off-white solid, mp 185.3 ${ }^{\circ} \mathrm{C} .{ }^{1} \mathrm{H}$ NMR $\left(\mathrm{CD}_{3} \mathrm{OD}\right): \delta 7.71(\mathrm{~d}, J=4.1 \mathrm{~Hz}, 4 \mathrm{H}), 6.54(\mathrm{~s}$, 1H), 6.46 (s, 1H), 6.28 (s, 1H). ${ }^{13} \mathrm{C}$ NMR: $161.37,149.29,145.45$, $141.33,129.61,129.27,128.86,128.43,126.95,126.31,126.28$, 125.12, 125.07, 125.02, 124.97, 122.69, 118.16, 105.83, 103.95, 102.02. MS $(\mathrm{m} / \mathrm{z}): 254.19\left(\mathrm{MH}^{+}\right)$.

4'-Chloro-5-(7-chloroquinolin-4-ylamino)-biphenyl-3-ol (11a). A solution of compound 10a (3 g, $13.66 \mathrm{mmol}$ ) and 4,7dichloroquinoline $(2.71 \mathrm{~g}, 13.66 \mathrm{mmol})$ in ethanol $(35 \mathrm{~mL})$ was heated at reflux for $2 \mathrm{~h}$. The reaction mixture was allowed to cool to room temperature. The resulting precipitate was collected, washed with ethanol, and dried to give $5.1 \mathrm{~g}(98 \%)$ of $11 \mathrm{a}$ as a yellow solid, $\mathrm{mp}>300{ }^{\circ} \mathrm{C}$ dec. ${ }^{1} \mathrm{H}$ NMR $\left(\mathrm{CD}_{3} \mathrm{OD}\right)$ : see Table $1 .{ }^{13} \mathrm{C}$ NMR: $168.66,150.92,150.48,148.81,141.34,140.85,140.53$, $135.07,132.28,128.17,127.93,126.20,124.86,123.42,118.05$, 114.80, 113.45, 108.07, 101.42. MS $(\mathrm{m} / \mathrm{z}): 280.9\left(\mathrm{MH}^{+}\right)$. Anal. $\left(\mathrm{C}_{21} \mathrm{H}_{14} \mathrm{~N}_{2} \mathrm{OCl}_{2} \cdot 0.4 \mathrm{H}_{2} \mathrm{O}\right) \mathrm{C}, \mathrm{H}, \mathrm{N}$.

5-(7-Chloro-quinolin-4-ylamino)-4'-trifluoromethyl-biphenyl3-ol (11b). Compound 11b was prepared by the same procedure as described for the preparation of 11a in a quantitative yield, $\mathrm{mp}$ $260{ }^{\circ} \mathrm{C}$. ${ }^{1} \mathrm{H}$ NMR $\left(\mathrm{CD}_{3} \mathrm{OD}\right)$ : as shown in Table $1 .{ }^{13} \mathrm{C}$ NMR: 158.96, 151.11, 149.61, 148.86, 144.48, 142.00, 141.68, 135.43, $129.28,128.97,127.16,126.39,126.11,125.40,125.34,125.29$, $125.24,123.39,118.37,112.88,110.38,109.53,101.96 . \mathrm{MS}(\mathrm{m} /$ z): $415.10\left(\mathrm{MH}^{+}\right)$. Anal. $\left(\mathrm{C}_{22} \mathrm{H}_{14} \mathrm{~N}_{2} \mathrm{OClF}_{3} \cdot 0.9 \mathrm{H}_{2} \mathrm{O}\right) \mathrm{C}, \mathrm{H}, \mathrm{N}$.

General Procedure for Synthesis of Mannich Base. A mixture of tert-butylamine $(23 \mathrm{mmol})$ and $37 \%$ formaline $(28 \mathrm{mmol})$ in $\mathrm{N}, \mathrm{N}$-dimethylformamide $(10 \mathrm{~mL})$ was added to a solution of compound 11 (7 mmol) in $N, N$-dimethylformamide $(30 \mathrm{~mL})$. The reaction mixture was stirred at room temperature for 3 days. The resulting precipitate was collected, washed with water followed by ethanol, and recrystallized from chloroform to give bis-substituted Mannich base $\mathbf{3}$ as a pale yellow solid in $40 \%$ yield. The dimethylformamide filtrates were combined and diluted with cool water $(100 \mathrm{~mL})$. The precipitate obtained was collected, washed with water, and dried. The crude product was purified by silica gel column chromatography eluting with mixture of $\mathrm{CHCl}_{3}$ :EtOAc: $\mathrm{MeOH}$ (10:1:1) to give compounds 2 and $\mathbf{5}$ which were recrystallized from $\mathrm{CHCl}_{3}$ /ether. Fractions, which contained both compounds $\mathbf{1}$ and $\mathbf{4}$, were collected and evaporated in vacuum to dryness. The products were separated by fractional crystallization from methanol to give first pure $\mathbf{1}$, and then compound $\mathbf{4}$, which was recrystallized from ether.

6-(tert-Butylaminomethyl)-4'-chloro-5-(7-chloroquinolin-4ylamino)-biphenyl-3-ol (1a). Yield: $18 \%, \mathrm{mp}>220{ }^{\circ} \mathrm{C}$ dec. ${ }^{1} \mathrm{H}$ NMR $\left(\mathrm{CD}_{3} \mathrm{OD}\right)$ : see Table $1 .{ }^{13} \mathrm{C}$ NMR: $163.48,150.99,149.59$, $148.88,143.04,140.23,139.57,135.31,133.05,130.82,128.07$, 126.36, 125.23, 123.38, 118.31, 116.00, 112.92, 111.12, 101.76, 52.66, 41.24, 25.85. MS (m/z): $466.0\left(\mathrm{MH}^{+}\right)$. Anal. $\left(\mathrm{C}_{26} \mathrm{H}_{25} \mathrm{~N}_{3^{-}}\right.$ $\left.\mathrm{OCl}_{2} \cdot 0.2 \mathrm{H}_{2} \mathrm{O}\right) \mathrm{C}, \mathrm{H}, \mathrm{N}$.

6-(tert-Butylaminomethyl)-5-(7-chloroquinolin-4-ylamino)-4' trifluoromethyl-biphenyl-3-ol (1b). Yield: $20 \%, \mathrm{mp}>220^{\circ} \mathrm{C} \mathrm{dec}$. ${ }^{1} \mathrm{H}$ NMR $\left(\mathrm{CD}_{3} \mathrm{OD}\right)$ : see Table $1 .{ }^{13} \mathrm{C}$ NMR: $163.69,151.01$, $149.56,148.88,145.08,141.82,140.31,135.12,129.47,129.11$, $128.85,126.36,125.24,124.92,124.87,124.82,124.77,123.38$, $118.32,116.03,112.74,111.46,101.77,52.54,41.28,25.89 . \mathrm{MS}$ $(\mathrm{m} / \mathrm{z}): 250.6\left(\mathrm{M}+2 \mathrm{H}^{+}\right)$. Anal. $\left(\mathrm{C}_{27} \mathrm{H}_{25} \mathrm{~N}_{3} \mathrm{OClF}_{3}\right) \mathrm{C}, \mathrm{H}, \mathrm{N}$.

4-(tert-Butylaminomethyl)-4'-chloro-5-(7-chloroquinolin-4ylamino)-biphenyl-3-ol (2a). Yield: $10 \%, \mathrm{mp}>220{ }^{\circ} \mathrm{C}$ dec. ${ }^{1} \mathrm{H}$ NMR $\left(\mathrm{CD}_{3} \mathrm{OD}\right)$ : see Table $1 .{ }^{13} \mathrm{C}$ NMR: $161.52,151.21,150.79$, $148.89,141.14,139.01,138.42,135.44,133.14,128.53,127.85$, 126.49, 125.36, 123.17, 118.72, 117.94, 114.14, 113.11, 101.35, 52.17, 38.88, 26.29. MS (m/z): $466.0\left(\mathrm{MH}^{+}\right)$. Anal. $\left(\mathrm{C}_{26} \mathrm{H}_{25} \mathrm{~N}_{3^{-}}\right.$ $\left.\mathrm{OCl}_{2}\right) \mathrm{C}, \mathrm{H}, \mathrm{N}$.

4-(tert-Butylaminomethyl)-5-(7-chloroquinolin-4-ylamino)-4'trifluoromethyl-biphenyl-3-ol (2b). Yield: $10 \%, \mathrm{mp}>200{ }^{\circ} \mathrm{C} \mathrm{dec}$. ${ }^{1} \mathrm{H}$ NMR $\left(\mathrm{CD}_{3} \mathrm{OD}\right)$ : see Table $1 .{ }^{13} \mathrm{C}$ NMR: 163.80, 161.93, $152.00,151.22,150.74,140.77,138.93,135.45,130.64,129.28$, $126.94,126.50,125.43,125.38,125.31,125.26,123.18,119.35$, $117.63,114.25,113.51,101.36,52.80,38.99,26.29$. MS $(\mathrm{m} / z)$ : $500.0\left(\mathrm{MH}^{+}\right)$. Anal. $\left(\mathrm{C}_{27} \mathrm{H}_{25} \mathrm{~N}_{3} \mathrm{OClF}_{3}\right) \mathrm{C}, \mathrm{H}, \mathrm{N}$.

4,6-Bis-(tert-butylaminomethyl)-4'-chloro-5-(7-chloroquinolin4-ylamino)-biphenyl-3-ol (3a). Yield: $40 \%, \mathrm{mp}>220{ }^{\circ} \mathrm{C} \mathrm{dec} .{ }^{1} \mathrm{H}$ NMR $\left(\mathrm{CD}_{3} \mathrm{OD}\right)$ : see Table $1 .{ }^{13} \mathrm{C}$ NMR: $160.04,151.12,150.43$, $148.71,141.11,139.38,137.98,135.34,133.04,130.38,128.05$, $126.49,125.40,123.15,120.15,118.54,117.66,114.98,101.06$, 52.21, 51.48, 41.18, 38.13, 26.76, 26.22. MS (m/z): $551.1\left(\mathrm{MH}^{+}\right)$. Anal. $\left(\mathrm{C}_{31} \mathrm{H}_{36} \mathrm{~N}_{4} \mathrm{OCl}_{2} \cdot 1.9 \mathrm{H}_{2} \mathrm{O}\right) \mathrm{C}, \mathrm{H}, \mathrm{N}$.

4,6-Bis-(tert-butylaminomethyl)-5-(7-chloroquinolin-4-ylamino)4'-trifluoromethyl-biphenyl-3-ol (3b). Yield: $43 \%$, mp $196{ }^{\circ} \mathrm{C}$. ${ }^{1} \mathrm{H}$ NMR $\left(\mathrm{CD}_{3} \mathrm{OD}\right)$ : see Table $1 .{ }^{13} \mathrm{C}$ NMR: 162.32, 151.13, $150.29,148.73,144.94,140.55,137.99,135.36,129.54,129.31$, $128.80,126.50,125.24,124.83,124.79,124.75,124.70,123.13$, 121.15, 119.01, 117.68, 114.92, 101.01, 51.64, 50.89, 41.16, 37.99, 27.07, 26.45. MS $(m / z): 293.1\left(\mathrm{M}^{+}+2 \mathrm{H}\right)$. Anal. $\left(\mathrm{C}_{32} \mathrm{H}_{36} \mathrm{~N}_{4} \mathrm{OClF}_{3}\right)$ $\mathrm{C}, \mathrm{H}, \mathrm{N}$.

2,6-Bis-(tert-butylaminomethyl)-4'-chloro-5-(7-chloroquinolin4-ylamino)-biphenyl-3-ol (4a). Yield: $7 \%, \mathrm{mp}>250{ }^{\circ} \mathrm{C}$ dec. ${ }^{1} \mathrm{H}$ NMR $\left(\mathrm{CD}_{3} \mathrm{OD}\right)$ : see Table $1 .{ }^{13} \mathrm{C} \mathrm{NMR}\left(\mathrm{CD}_{3} \mathrm{OD}\right): 161.73,151.26$, 149.07, 148.93, 141.91, 140.30, 138.05, 135.43, 133.30, 130.65, $128.34,126.80,125.25,125.00,122.94,119.56,118.13,117.18$, $110.90,101.18,52.48,50.29,41.89,40.85,27.44,26.08$. MS (m/ z): $551.1\left(\mathrm{MH}^{+}\right)$. Anal. $\left(\mathrm{C}_{31} \mathrm{H}_{36} \mathrm{~N}_{4} \mathrm{OCl}_{2} \cdot 0.75 \mathrm{H}_{2} \mathrm{O}\right) \mathrm{C}, \mathrm{H}, \mathrm{N}$.

${ }^{1} \mathrm{H} \mathrm{NMR}\left(\mathrm{CDCl}_{3}\right): \delta 10.22(\mathrm{bs}, 1 \mathrm{H}), 8.58(\mathrm{~d}, J=5.6 \mathrm{~Hz}, 1 \mathrm{H})$, $8.05(\mathrm{~d}, J=9.0 \mathrm{~Hz}, 1 \mathrm{H}), 8.02(\mathrm{~d}, J=2.1 \mathrm{~Hz}, 1 \mathrm{H}), 7.45(\mathrm{~d}, J=$ $8.6 \mathrm{~Hz}, 2 \mathrm{H}), 7.43(\mathrm{dd}, J=2.1,9.0 \mathrm{~Hz}, 1 \mathrm{H}), 7.27(\mathrm{~d}, J=5.6,1 \mathrm{H})$, $7.12(\mathrm{~d}, J=8.6 \mathrm{~Hz}, 2 \mathrm{H}, \mathrm{s}, 1 \mathrm{H}), 3.62(\mathrm{~s}, 2 \mathrm{H}), 3.36(\mathrm{~s}, 2 \mathrm{H}), 1.12(\mathrm{~s}$, $9 \mathrm{H}), 1.05(\mathrm{~s}, 9 \mathrm{H}) .{ }^{13} \mathrm{C} \mathrm{NMR}\left(\mathrm{CDCl}_{3}\right): 158.82,152.16,150.04$, $146.74,141.15,140.46,138.11,135.01,133.40,129.95,128.70$, $128.65,125.46,122.48,119.07,118.94,116.20,107.51,102.38$, $51.31,50.68,43.27,41.84,28.82,28.44$. 
2,6-Bis-(tert-butylaminomethyl)-5-(7-chloroquinolin-4-ylamino)$4^{\prime}$-trifluoromethyl-biphenyl-3-ol (4b). Yield: $7 \%, \mathrm{mp}>250^{\circ} \mathrm{C}$ dec. ${ }^{1} \mathrm{H}$ NMR $\left(\mathrm{CD}_{3} \mathrm{OD}\right)$ : see Table $1 .{ }^{13} \mathrm{C}$ NMR $\left(\mathrm{CD}_{3} \mathrm{OD}\right): 161.46$, $151.23,148.89,143.60,141.76,140.43,135.44,129.94,129.70$, $129.26,126.45,125.30,125.04,124.98,123.03,119.22,118.14$, 116.69, 110.94, 101.13, 52.69, 50.19, 41.74, 40.76, 27.19, 25.80 . MS $(m / z): 293.1\left(\mathbf{M}^{+}+2 \mathrm{H}\right)$. Anal. $\left(\mathrm{C}_{32} \mathrm{H}_{36} \mathrm{~N}_{4} \mathrm{OClF}_{3}\right) \mathrm{C}, \mathrm{H}, \mathrm{N}$.

${ }^{1} \mathrm{H} \mathrm{NMR}\left(\mathrm{CDCl}_{3}\right): \delta 8.58(\mathrm{~d}, J=5.6 \mathrm{~Hz}, 1 \mathrm{H}), 8.03(\mathrm{~m}, 2 \mathrm{H})$, $7.74(\mathrm{~d}, J=8.1 \mathrm{~Hz}, 2 \mathrm{H}), 7.44(\mathrm{dd}, J=2.1,9.0 \mathrm{~Hz}, 1 \mathrm{H}), 7.73(\mathrm{~d}$, $J=8.1 \mathrm{~Hz}, 2 \mathrm{H}), 7.26(\mathrm{~d}, J=5.6,1 \mathrm{H}), 7.14(\mathrm{~s}, 1 \mathrm{H}), 3.59(\mathrm{~s}, 2 \mathrm{H})$, $3.32(\mathrm{~s}, 2 \mathrm{H}), 1.10(\mathrm{~s}, 9 \mathrm{H}), 1.02(\mathrm{~s}, 9 \mathrm{H}) .{ }^{13} \mathrm{C} \mathrm{NMR}\left(\mathrm{CDCl}_{3}\right): 159.09$, $152.05,149.92,147.51,143.59,141.21,140.45,135.25,130.05$, $129.47,129.10,128.77,125.61,125.56,125.50,125.42,122.47$, $118.78,118.67,116.05,107.87,102.39,51.39,50.56,43.22,41.74$, 28.69, 28.38 .

2-(tert-Butylaminomethyl)-5-(7-chloroquinolin-4-ylamino)-4'trifluoromethyl-biphenyl-3-ol (5b). Yield: $2 \%, \mathrm{mp}>250{ }^{\circ} \mathrm{C} \mathrm{dec}$. ${ }^{1} \mathrm{H}$ NMR $\left(\mathrm{CD}_{3} \mathrm{OD}\right)$ : see Table $1 .{ }^{13} \mathrm{C}$ NMR $\left(\mathrm{CD}_{3} \mathrm{OD}\right): 157.09$, $152.71,150.04,147.16,145.67,143.19,142.35,134.51,130.27$, $128.59,128.50,128.08,127.65,126.63,125.72,125.36,125.33$, $123.66,123.02,119.92,118.77,116.69,112.31,107.58,102.35$, 50.83, 41.47, 28.68. MS $(\mathrm{m} / \mathrm{z}): 250.6\left(\mathrm{M}^{+}+2 \mathrm{H}\right)$. Anal. $\left(\mathrm{C}_{27} \mathrm{H}_{25} \mathrm{~N}_{3^{-}}\right.$ $\left.\mathrm{OClF}_{3} \cdot 0.25 \mathrm{H}_{2} \mathrm{O}\right) \mathrm{C}, \mathrm{H}, \mathrm{N}$

${ }^{1} \mathrm{H}$ NMR $\left(\mathrm{CDCl}_{3}\right): \delta 8.61(\mathrm{~d}, J=5.6 \mathrm{~Hz}, 1 \mathrm{H}), 8.05(\mathrm{~d}, J=2.1$ $\mathrm{Hz}, 1 \mathrm{H}), 7.93$ (d, $J=9.0 \mathrm{~Hz}, 1 \mathrm{H}), 7.73$ (d, $J=8.1 \mathrm{~Hz}, 2 \mathrm{H}), 7.47$ $(\mathrm{d}, J=8.1 \mathrm{~Hz}, 1 \mathrm{H}), 7.44(\mathrm{dd}, J=2.1$ and $9.0 \mathrm{~Hz}, 1 \mathrm{H}), 7.32(\mathrm{~d}, J$ $=5.6,1 \mathrm{H}), 6.99(\mathrm{~d}, J=2.1 \mathrm{~Hz}, 1 \mathrm{H}), 6.64(\mathrm{~d}, J=2.1 \mathrm{~Hz}, 1 \mathrm{H})$, $3.66(\mathrm{~s}, 2 \mathrm{H}), 1.32(\mathrm{~s}, 9 \mathrm{H})$.

4'-Chloro-5-(7-chloro-1-oxy-quinolin-4-ylamino)-biphenyl-3ol (12). Compound 12 was prepared by the same method as that for synthesis of 11a in a quantitative yield starting from 4,7dichloroquinoline 1-oxide, $\mathrm{mp}>300{ }^{\circ} \mathrm{C}$ dec. ${ }^{1} \mathrm{H}$ NMR $\left(\mathrm{CD}_{3} \mathrm{OD}\right)$ : $\delta 8.61(\mathrm{~d}, J=9.0 \mathrm{~Hz}, 1 \mathrm{H}, \mathrm{e}), 8.59(\mathrm{~d}, J=7.3 \mathrm{~Hz}, 1 \mathrm{H}), 8.40(\mathrm{~d}$, $J=2.1 \mathrm{~Hz}, 1 \mathrm{H}), 7.87(\mathrm{dd}, J=2.1,9.0 \mathrm{~Hz}, 1 \mathrm{H}), 7.64(\mathrm{~d}, J=8.6$ $\mathrm{Hz}, 2 \mathrm{H}), 7.48$ (d, $J=8.6 \mathrm{~Hz}, 2 \mathrm{H}), 7.18$ (br s, $1 \mathrm{H}), 7.11$ (br s, $1 \mathrm{H}$ ), $7.00(\mathrm{~d}, J=7.3 \mathrm{~Hz}, 1 \mathrm{H}), 6.88(\mathrm{br} \mathrm{s}, 1 \mathrm{H}) . \mathrm{MS}(\mathrm{m} / \mathrm{z}): 397.2\left(\mathrm{MH}^{+}\right)$. Anal. $\left(\mathrm{C}_{21} \mathrm{H}_{14} \mathrm{~N}_{2} \mathrm{O}_{2} \mathrm{Cl}_{2} \cdot 0.3 \mathrm{H}_{2} \mathrm{O}\right) \mathrm{C}, \mathrm{H}, \mathrm{N}$.

6-(tert-Butylaminomethyl)-4'-chloro-5-(7-chloro-1-oxy-quinolin-4-ylamino)-biphenyl-3-ol (13). To a suspension of compound $12(4,3 \mathrm{~g}, 10.83 \mathrm{mmol})$ in DMF $(300 \mathrm{~mL})$ was added tertbutylamine $(2.3 \mathrm{~mL}, 21.66 \mathrm{mmol})$ followed by $0.6 \mathrm{~mL}(21.66$ $\mathrm{mmol}$ ) of $37 \%$ formaldehyde. The mixture was heated at $65^{\circ} \mathrm{C}$ for 1 day, and another equivalent mole each of tert-butylamine (1.15 $\mathrm{mL}, 10.83 \mathrm{mmol})$ and $37 \%$ formaldehyde $(0.3 \mathrm{~mL}, 10.83 \mathrm{mmol})$ were added. Since tert-butylamine and formaldehyde are volatile, some of these reagents were lost during the heating, even with a water-cooling condenser. Over the course of 7 days, an additional 10 equiv of tert-butylamine and $37 \%$ formaldehyde were added. The reaction was cooled to room temperature, and insoluble starting material was recovered. The solvent was removed in vacuum. The residue was purified by silica gel column chromatography eluting with $\mathrm{CHCl}_{3}$ :EtOAc:MeOH: $\mathrm{NH}_{4} \mathrm{OH}$ (10:1:1:0.04) to give crude product. Recrystallization from EtOAc yielded $0.74 \mathrm{~g} \mathrm{(14 \% )}$ of pure final product 13 as a bright yellow solid, $\mathrm{mp}>250{ }^{\circ} \mathrm{C}$ dec. ${ }^{1} \mathrm{H}$ NMR $\left(\mathrm{CD}_{3} \mathrm{OD}\right)$ : see Table $1 .{ }^{13} \mathrm{C}$ NMR $\left(\mathrm{CD}_{3} \mathrm{OD}\right): \delta$ 161.57, $146.72,141.31,140.20,139.23,138.72,138.31,137.99,133.43$, $128.61,127.96,127.90,124.27,118.87,118.37,118.19,114.10$, 113.56, 100.49, 51.93, 38.89, 26.78. MS (m/z): $482\left(\mathrm{MH}^{+}\right)$. Anal. $\left(\mathrm{C}_{26} \mathrm{H}_{25} \mathrm{~N}_{3} \mathrm{O}_{2} \mathrm{Cl}_{2} \cdot \mathrm{H}_{2} \mathrm{O}\right) \mathrm{C}, \mathrm{H}, \mathrm{N}, \mathrm{Cl}$

4,6-Bis-(tert-butylaminomethyl)-4'-chloro-5-(7-chloro-1-oxyquinolin-4-ylamino)-biphenyl-3-ol (14). Compound 14 was isolated from the same reaction mixture as compound $\mathbf{1 3}$. Yield: $25 \%$, $\mathrm{mp}>250{ }^{\circ} \mathrm{C}$ dec. ${ }^{1} \mathrm{H}$ NMR $\left(\mathrm{CD}_{3} \mathrm{OD}\right)$ : see Table $1 .{ }^{13} \mathrm{C} \mathrm{NMR}\left(\mathrm{CD}_{3}-\right.$ OD): $\delta 167.11,146.75,143.16,140.13,139.23,138.53,138.23$, $137.84,133.51130 .28,128.29,127.89,124.69,118.21,118.12$, $116.49,115.84,114.06,100.73,55.48,55.05,41.18,38.98,24.88$. MS $(\mathrm{m} / \mathrm{z}): 284.17\left(\mathrm{M}^{+}+2 \mathrm{H}\right)$. Anal. $\left(\mathrm{C}_{31} \mathrm{H}_{36} \mathrm{~N}_{4} \mathrm{O}_{2} \mathrm{Cl}_{2} \cdot 0.3 \mathrm{H}_{2} \mathrm{O}\right) \mathrm{C}$, $\mathrm{H}, \mathrm{N}$.

Biological Studies. (i) In Vitro Antimalarial Studies. The in vitro assays were conducted by using a modification of the semiautomated microdilution technique of Desjardins et al. ${ }^{22}$ and
Table 2. Growth Inhibition of Isoquine Analogues against $P$. falciparum and Macrophage Line J774 Cell Lines

\begin{tabular}{|c|c|c|c|c|}
\hline \multirow[b]{2}{*}{ compd } & \multirow{2}{*}{$\begin{array}{c}\text { macrophage } \\
\text { line } \mathrm{J} 774 \\
\left(\mathrm{IC}_{50}, \mu \mathrm{g} / \mathrm{mL}\right)\end{array}$} & \multicolumn{3}{|c|}{$\begin{array}{l}\text { P. falciparum } \\
\left(\mathrm{IC}_{50} \mathrm{ng} / \mathrm{mL}\right)\end{array}$} \\
\hline & & D6 & W2 & TM91C235 \\
\hline $1 \mathbf{a}$ & $6.1 \pm 0.3$ & 0.3 & 0.4 & 1.78 \\
\hline $1 \mathrm{~b}$ & $11.6 \pm 1.2$ & 7.1 & 130.0 & 63.0 \\
\hline $2 \mathbf{a}$ & $1.6 \pm 0.3$ & 1.4 & 1.6 & 1.7 \\
\hline $2 \mathbf{b}$ & $1.7 \pm 0.3$ & 1.8 & 2.1 & 1.8 \\
\hline $\mathbf{3 a}$ & $3.6 \pm 01$ & 2.2 & 2.6 & 2.3 \\
\hline 3b & $0.75 \pm 0.2$ & 1.9 & 2.8 & 2.0 \\
\hline $4 \mathbf{a}$ & $2.8 \pm 0.3$ & 2.8 & 5.3 & 2.5 \\
\hline $4 b$ & ND & 1.8 & 3.6 & 3.0 \\
\hline $5 \mathbf{b}$ & ND & 1.2 & 14.0 & 73 \\
\hline 11a & ND & 8.8 & 22.4 & N/A \\
\hline 11b & ND & 15 & 300 & 140 \\
\hline 12 & ND & 397 & $>1000$ & 580 \\
\hline 13 & ND & 4.3 & 9.2 & 8.8 \\
\hline 14 & ND & 4.1 & 9.1 & 8.5 \\
\hline tebuquine- $N^{\omega}$-oxide & 7.2 & 1.5 & 0.9 & 2.3 \\
\hline tebuquine & 1.8 & 0.1 & 0.04 & N/A \\
\hline chloroquine & ND & 2.96 & 143.77 & 31.86 \\
\hline
\end{tabular}

Chulay et al. ${ }^{23}$ Three $P$. falciparum malaria parasite clones, from CDC Indochina III (W-2), CDC Sierra Leone I (D-6), and Southeast Asia Isolates (TM91C235), were utilized in susceptibility testing. They were derived by direct visualization and micromanipulation from patient isolates. ${ }^{24}$ The W-2 clone is susceptible to mefloquine (MQ) but resistant to chloroquine (CQ), sulfadoxine, pyrimethamine, and quinine, whereas the D-6 clone is naturally resistant to MQ but susceptible to $\mathrm{CQ}$, sulfadoxine, pyrimethamine, and quinine. The TM91C235 is a multi-drug resistance $P$. falciparum isolate from Southeast Asia. Test compounds were initially dissolved in DMSO and diluted 400-fold in RPMI 1640 culture medium supplemented with $25 \mathrm{mM}$ Hepes, $32 \mathrm{mM} \mathrm{NaHCO}$, and $10 \%$ Albumax I (Gibco BRL, Grand Island, NY). These solutions were subsequently serially diluted 2-fold with a Biomek 1000 (Beckman, Fullerton, CA) over 11 different concentrations. The parasites were exposed to serial dilutions of each compound for $48 \mathrm{~h}$ and incubated at $37{ }^{\circ} \mathrm{C}$ with $5 \% \mathrm{O}_{2}, 5 \% \mathrm{CO}_{2}$, and $90 \% \mathrm{~N}_{2}$ prior to the addition of $\left[{ }^{3} \mathrm{H}\right]$-hypoxanthine. After a further incubation of $18 \mathrm{~h}$, parasite DNA was harvested from each microtiter well using Packard Filtermate 196 Harvester (Meriden, CT) onto glass filters. Uptake of $\left[{ }^{3} \mathrm{H}\right]$-hypoxanthine was measured with a Packard Topcount Scintillation. Concentration-response data were analyzed by a nonlinear regression logistic dose response model, and the $\mathrm{IC}_{50}$ values (50\% inhibitory concentrations) for each compound were calculated. The results are shown in Table 2.

(ii) In Vitro Toxicity Assay. Selected compounds were tested for toxicity in vitro against a subclone (G8) of the murine monocytelike macrophage line J774. The cell line was obtained from Dr. Jose Alunda, Departmento de Sanidad Animal, Facultad de Veterinaria, Universidad Complutense, Madrid, Spain. Murine cells were maintained in $75 \mathrm{~cm}^{2}$ tissue culture flasks in Dulbecco's modified Eagle medium (GIBCO) supplemented with $10 \%$ fetal calf serum, $2 \mathrm{mM}$ 1-glutamine $50 \mu \mathrm{g} / \mathrm{mL}$ gentamicin under humidified $5 \% \mathrm{CO}_{2} / 95 \%$ air at $37{ }^{\circ} \mathrm{C}$.

Toxicity tests were performed in 96-well tissue culture plates using an aqueous tetrazolium/formazan system as described. ${ }^{25}$ Cells were plated at a density of $1 \times 10^{4}$ cells/well in $100 \mu \mathrm{L}$ of culture medium. After $24 \mathrm{~h}$ under culture conditions, $10 \mu \mathrm{L}$ of drug (experimental) or solvent (control) diluted to the appropriate concentration in culture medium was added to each well. After the mixture was incubated for $72 \mathrm{~h}, 20 \mu \mathrm{L}$ of a solution containing 3-(4,5-dimethylthiazol-2-yl)-5-(3-carboxymethoxy-phenyl)-2-(4sulfo-phenyl)- $2 H$-tetrazolium, inner salt (MTS), (Technical Bulletin: CellTiter 96 AQeousOne Solution Cell Proliferation Assay Technical Bulletin \#TB245, Promega Corporation) was added, and the plates were cultured for 1 to $2 \mathrm{~h}$ at $37^{\circ} \mathrm{C}$. A Spectra MAX Plus microtiter plate reader (Molecular devices) was used to measure the optical density (OD) at a wavelength of $490 \mathrm{~nm}$. Solvent control values were subtracted from experimental values. 


\section{Scheme 5}<smiles>CCN(CC)CCc1cc(Nc2ccnc3cc(Cl)ccc23)ccc1O</smiles><smiles>C=C1C=CC(Nc2ccnc3cc(Cl)ccc23)C(CC(C)C)C1=O</smiles>

(iii). Antimalarial Studies against $\boldsymbol{P}$. berghei in Mice. The in vivo efficacy of the new compounds was determined in a modified Thompson test. ${ }^{26,27}$ This test measures the survivability of mice and parasite clearance following administration of drug on day 3-5 post infection. In brief, $5 \times 10^{6} \mathrm{P}$. berghei-infected erythrocytes (KBG-173 strain) were inoculated into the intraperitoneal cavity of male mice that weighed $24-30 \mathrm{~g}$. By day 3 post-infection, parasitemia ranged from 1.0 to $3.7 \%$. Each drug, suspended in $0.5 \%$ hydroxyethylcellulose $-0.1 \%$ Tween 80 , was administered orally (PO) once daily from day 3-5 post-infection. The volume of drug suspension given depends on the weight of the mouse and the drug concentration of the suspension. In general, the volume is given at $0.01 \mathrm{~mL} / \mathrm{gram}$ of body weight.

Five mice were used in each dosage group. Blood films were taken on day 6 and biweekly for 31 days. Mice blood film negative on day 31 post-infection were considered cured (C). Compounds were considered active (A) when the survival time of the treated mice was greater than twice the control mice, i.e., 12-14 day. Mice losing $>20 \%$ of their body weight were sacrificed.

\section{Results and Discussion}

In Vitro Antimalarial Activity. The antimalarial activity of the new isotebuquine analogues was assessed against both CQsusceptible (D6) and CQ-resistant clones (W2 and TM91C235) of $P$. falciparum (Table 2). Tebuquine $N^{\omega}$-oxide and chloroquine were used as positive control for the study. Chloro derivative 1a $\left(\mathrm{IC}_{50} 0.3 \mathrm{ng} / \mathrm{mL}\right)$ is the most active among the compounds tested and is 20-fold more active than the corresponding trifluoromethyl analogue 1b. No appreciable difference in antimalarial activities between chloro $(\mathbf{2 a - 4 a )}$ and trifluoromethyl $(\mathbf{2} \mathbf{b}-\mathbf{5 b})$ analogues, however, were observed. The new analogues were better than or equal to tebuquine in growth inhibition against all three clones of $P$. falciparum studied. There appeared no cross resistance with CQ, except $\mathbf{1 b}$. In general, compounds with mono Mannich base side chain (1a and 2a) are more active than those with two Mannich base functions (3a and 4a). It is to be noted that the key intermediates 11a and 11b which possess no Mannich base side chain are also highly active against $\mathrm{W} 2$ clone in the test, with $\mathrm{IC}_{50}$ of 8.8 and $15 \mathrm{ng} / \mathrm{mL}$, respectively. However, both showed cross resistance to $\mathrm{CQ}$, with $\mathrm{IC}_{50}$ of 22.4 and $300 \mathrm{ng} / \mathrm{mL}$, respectively, against D-6, a CQ-resistant cell line. The results are of no surprise from the structure-activity relationship and mechanism of action points of view. Structurally, intermediate $\mathbf{1 1 a}$ and $\mathbf{1 1 b}$ are analogues of $\mathrm{CQ}$, while compounds $\mathbf{1 - 5}$ are isotebuquine analogues.

The amodiaquine was metabolized to an active metabolite, iminoquinone, which acts as an alkylating agent and is believed to be responsible for the toxicity and antimalarial activity observed. The isoquine analogues, however, cannot form iminoquinone, yet potentially can form $o$-quinone methide (Scheme 5) which, like iminoquinone, is an alkylating agent. Lacking a Mannich base side chain to generate quinone methide active metabolite, compounds $\mathbf{1 1 a}$ and $\mathbf{1 1 b}$ are expected to act as chloroquine analogues rather than isoquine analogues and thus showed cross resistance with CQ. As expected, compounds with mono- or bis-Mannich base side chains showed no or minimum cross resistance to chloroquine (Table 2). The results clearly indicate that the mechanisms of action of the isoquine and the chloroquine are different, although both are 4-aminoquinpline derivatives.

In Vivo Antimalarial Activity against $P$. berghei in Mice. The three most active compounds $-\mathbf{1 a}, \mathbf{2} \mathbf{a}$, and $\mathbf{3} \mathbf{a}$-were tested in mice infected with $P$. berghei by oral administration (Thompson test). None showed significant activity on 3-day treatment with a daily dose up to $192 \mathrm{mg} / \mathrm{kg}$. Likewise, the $N$-oxide analogues, 13 and $\mathbf{1 4}$, possess only marginal activity with a minimum active dose of $450 \mathrm{mg} / \mathrm{kg}$. The marginal efficacy results in Thompson test may be a result of poor oral bioavailability of these compounds

In Vitro Toxicity. Macrophage line $\mathrm{J} 774$ was used to assess the toxicity of the new Mannich base analogues synthesized in this study (Table 2). The results indicated that the concentration required to inhibit the normal cell line growth is 1000-fold higher than that for the inhibition of parasite growth, especially the chloroquine-sensitive cell line D-6, with therapeutic index of $\geq 1000$ and is comparable to that of the positive control drug, tebuquine and tebuquine $N^{\omega}$-oxide.

\section{Conclusion}

Methods for synthesis of isotebuquine analogues and their $N^{\omega}$-oxides have been developed. New derivatives exhibit promising in vitro antimalarial activity against both chloroquinesensitive (D6) and chloroquine-resistant (W2) clones of $P$. falciparum cell growth at a concentration comparable to that of tebuquine. However, the new isotebuquine analogues showed only marginal antimalarial activity in the Thompson test against $P$. berghei by oral administration. The poor solubility in organic solvents and water may be partially responsible for the poor oral activity observed.

Acknowledgment. Material has been reviewed by the Walter Reed Army Institute of Research. There is no objection to its presentation and/or publications. The opinions or assertions contained herein are the private views of the author, and they are not to be construed as official or as reflecting true views of the Department of the Army or the Department of Defense. Dr. Miroshnikova gratefully acknowledges the National Research Council for the NRC Associateship. This research was performed while the author held a National Research Council Research Associateship Award at the Walter Reed Army Institute of Research.

Supporting Information Available: Elemental analysis results. This material is available free of charge via the Internet at http:// pubs.acs.org.

\section{References}

(1) World Health Organization. Severe and complicated malaria. W.H.O. malaria action programme. Trans. R. Soc. Trop. Med. Hyg. 1986, $80,3-50$.

(2) White, N. J. Drug resistance in malaria. Br. Med. Bull. 1998, 54, $703-715$

(3) Watkins, W. M.; Sixsmith, D. G.; Spencer, H. G.; Boriga, D. A.; Karjuki, D. M.; Kipingor, T.; Koech, D. K. Effectiveness of amodiaquine as a treatment for chloroquine resistant Plasmodium falciparum. Lancet 1984, 1, 357-359.

(4) Neftel, K. A.; Woodtly, W.; Schmid, M. Amodiaquine induced agranulocytosis and liver damage. Br. Med. J. 1986, 292, 721-723. 
(5) Lind, R. E.; Levi, J. A.; Vincent, P. C. Amodiaquine induced agranulocytosis; toxic effects of Amodiaquine in bone marrow culture in vitro. Br. Med. J. 1973, 1, 458-460.

(6) Maggs, J. L.; Kitteringham, N. R.; Clarke, J. B.; Park, B. K. Drug protein conjugate-mechanism of formation of protein arylating intermediates from amodiaquine, a myelotoxin and hepatotoxin in man. Biochem. Pharmacol. 1988, 37, 303-311.

(7) Naisbitt, D. J.; Ruscoe, J. E.; Williams, D.; O’Neil, P. M.; Pirmohamed, M.; Park, B. K. Disposition of amodiaquine and related antimalarial agents in human neutrophiles: Implications for drug design. J. Pharmacol. Exp. Ther. 1997, 280, 884-893.

(8) Naisbitt, D. J.; Williams, D. P.; O’Neill, P. M.; Magg, J. L.; Willock, D. J.; Pirmohamed, M.; Park, B. K. Metabolism-dependent neutrophil cytotoxicity of amodiaquine: A comparison with pyronaridine and related antimalarial drugs. Chem. Res. Toxicol. 1998, 11, 1586-1595.

(9) Ruscoe, J. E.; Tingle, M. D.; O’Neill, P. M.; Ward, S. A.; Park, B. K. Effect of disposition of Mannich antimalarial agents on the pharmacology and toxicology. Antimicrob. Agents Chemother. 1998, 42, 2410-2416.

(10) O’Neil, P. M.; Mukhtar, A.; Stocks, P. A.; Randle, L. E.; Hindley, S.; Ward, S. A.; Storr, R. C.; Bickley, J. F.; O’Neil, I. A.; Maggs, J. L.; Hughes, R. H.; Winstanley, P. A.; Bray, P. G.; Park, B. K. Isoquine and related amodiaquine analogues: A new generation of improved 4-aminoquinoline antimalarials. J. Med Chem. 2003, 46, 4933-4945.

(11) O’Neill, P. M.; Harrison, A. C.; Storr, R. C.; Hawley, S. R.; Ward, S. A.; Park, B. K. The effect of fluorine substitution on the metabolism and antimalarial activity of amodiaquine. J. Med. Chem. 1994, 37, 1362-1370

(12) O’Neill, P. M.; Hawley, S. R.; Storr, R. C.; Ward, S. A.; Park, B. K The Effect of fluorine substitution on the antimalarial activity of rebuquine. Bioorg. Med. Chem. Lett. 1996, 6, 391-392.

(13) Werbel, L. M.; Cook, P. D.; Elslager, E. F., Hung, J. H.; Johnson, J. L.; Kesten, S. J.; McNamara, D. J.; Ortwine, D. F.; Worth, D. F Synthesis, antimalarial activity, and quantitative structure-activity relationships of tebuquine and a series of related 5-[(7-chloro-4 quinolinyl)amino]-3-[(alkylamino)methyl][1,1'-biphenyl]-2-ols and $N^{\omega}$-oxides. J. Med. Chem. 1986, 29, 924-939.

(14) O’Neill, P. M.; Willock, D. J.; Hawley, S. R.; Bray, P. G.; Storr, R. C.; Ward, S. A.; Park, B. K. Synthesis, antimalarial activity, and molecular modeling of tebuquine analogues. J. Med. Chem. 1997, 40, 437-448

(15) Kesten, S. J.; Johnson, J.; Werbel, L. M. Synthesis and antimalarial effects of 4-[(7-chloro-4-quinolinyl)amino]-2-[(diethyl- amino)methyl]-6-alkylphenols and their $N^{\omega}$-oxides. J. Med. Chem. 1987, 30, 906-911.

(16) Duan, J.; Zhang, L. H.; Dolbierr, W. R. A convenient new method for the bromination of deactivated aromatic compounds. Syn. Lett. 1999, $1245-1246$

(17) Knyazev, V. N.; Drozd, V. N.; Klimov, A. A. Spirocyclic Meisenhemer complexes. VI. Intramolecular Meisenheimer 1,2-comlex from 1-( $\beta$-hydroxyethoxy)-3,5-dinitrobenzene. J. Org. Chem. USSR (Engl. transl.) 1976, 12, 2319-2323.

(18) Miyaura, N.; Yanagi, T.; Suzuki, A. The palladium-catalyzed crosscoupling reaction of phenylboronic acid with holoarenes in the presence of bases. Synth. Commun. 1981, 11, 513-519.

(19) Kotha, S.; Lahiri, K.; Dhurke Kashinath, D. Recent applications of the Suzuki-Miyaura cross-coupling reaction in organic synthesis. Tetrahedron 2002, 58, 9629-9757.

(20) Qian, Y.; Vogt, A.; Sebti, S. M.; Hamilton, A. D. Design and synthesis of non-peptide Ras CAAX mimetics as potent farnesyltransferase inhibitors. J. Med. Chem. 1996, 39, 217-223.

(21) Williard, P. G.; Fryhle, C. B. Boron trihalide-methyl sulfide complexes as convenient reagents for dealkylation of aryl ethers. Tetrahedron Lett. 1980, 21, 3731-3734.

(22) Desjardins, R. E.,; Canfield, C. J.; Haynes, D. E.; Chulay, J. D. Quantitative assessment of antimalarial activity in vitro by a semiautomated microdilution technique. Antimicrob. Agents Chemother. 1979, 16, 710-718.

(23) Chulay, J. D.; Haynes, D.; Diggs, C. L. Plasmodium falciparum: assessment of in vitro growth by $[3 \mathrm{H}]$-hypoxanthine incorporation. Exp. Parasitol. 1983, 55, 138-146.

(24) Oduola, A. M., Weatherly, N. F.; Bowdre, J. H.; Desjardins, R. E Plasmodium falciparum: cloning by single-erythrocyte micromanipulation and heterogeneity in vitro. Exp. Parasitol. 1988, 66, $86-95$.

(25) Cory, A. H.; Owen, T. C.; Barltrop, J. A.; Cory, J. G. Use of an aqueous soluble tetrazolium/formazan assay for cell growth assays in culture. Cancer Commun. 1991, 3, 207-212.

(26) Ager, A. L. Experimental models: rodent malaria models (in vivo). In Hand Book of Experimental Pharmacology: Antimalarial Drugs; Peters, W., Richards, W. H. G., Eds.; Springer-Verlag: Berlin, Heidelberg, New York, 1984; Chapter 8, Volume 68, pp 225-254.

(27) Sweeney, T. A. Survey of compounds from the antimalarial drug development program of the U. S. Army Medical Research and Development Command. Walter Reed Army Institute of Research, 1991, Vol 1

JM061232X 


\section{Supporting Information}

\section{Synthesis and Antimalarial Activity of New Isotebuquine Analogs}

Olga V. Miroshnikova, Thomas H. Hudson, Lucia Gerena, Dennis E. Kyle and Ai J. Lin*

Division of Experimental Therapeutics, Walter Reed Army Institute of Research, 503 Robert Grant Avenue, Silver Spring, Maryland 20910

\section{Elemental Analysis Data}

\begin{tabular}{|c|c|c|c|}
\hline Compd & Formula & Calcd & Found \\
\hline 1a & $\mathrm{C}_{26} \mathrm{H}_{25} \mathrm{~N}_{3} \mathrm{OCl}_{2} \cdot 0.2 \mathrm{H}_{2} \mathrm{O}$ & $\mathrm{C}, 66.44 ; \mathrm{H}, 5.45 ; \mathrm{N}, 8.94$ & $\mathrm{C}, 66.56 ; \mathrm{H}, 5.40 ; \mathrm{N}, 9.01$ \\
\hline $\mathbf{1 b}$ & $\mathrm{C}_{27} \mathrm{H}_{25} \mathrm{~N}_{3} \mathrm{OClF}_{3}$ & $\mathrm{C}, 64.86 ; \mathrm{H}, 5.04 ; \mathrm{N}, 8.40$ & $\mathrm{C}, 64.75 ; \mathrm{H}, 5.03 ; \mathrm{N}, 8.35$ \\
\hline $2 \mathbf{a}$ & $\mathrm{C}_{26} \mathrm{H}_{25} \mathrm{~N}_{3} \mathrm{OCl}_{2}$ & $\mathrm{C}, 66.95 ; \mathrm{H}, 5.40 ; \mathrm{N}, 9.01$ & $\mathrm{C}, 66.62 ; \mathrm{H}, 5.89 ; \mathrm{N}, 8.42$ \\
\hline $2 \mathbf{b}$ & $\mathrm{C}_{27} \mathrm{H}_{25} \mathrm{~N}_{3} \mathrm{OClF}_{3}$ & $\mathrm{C}, 64.86 ; \mathrm{H}, 5.04 ; \mathrm{N}, 8.40$ & $\mathrm{C}, 64.30 \mathrm{H}, 5.05 ; \mathrm{N}, 8.20$ \\
\hline $3 \mathbf{a}$ & $\mathrm{C}_{31} \mathrm{H}_{36} \mathrm{~N}_{4} \mathrm{OCl}_{2} \cdot 1.9 \mathrm{H}_{2} \mathrm{O}$ & $\mathrm{C}, 63.56 ; \mathrm{H}, 6.85 ; \mathrm{N}, 9.56$ & $\mathrm{C}, 63.66 ; \mathrm{H}, 6.54 ; \mathrm{N}, 9.46$ \\
\hline 3b & $\mathrm{C}_{32} \mathrm{H}_{36} \mathrm{~N}_{4} \mathrm{OClF}_{3}$ & $\mathrm{C}, 65.69 ; \mathrm{H}, 6.20 ; \mathrm{N}, 9.58$ & $\mathrm{C}, 65.77 ; \mathrm{H}, 6.15 ; \mathrm{N}, 9.47$ \\
\hline $4 a$ & $\mathrm{C}_{31} \mathrm{H}_{36} \mathrm{~N}_{4} \mathrm{OCl}_{2} \cdot 0.75 \mathrm{H}_{2} \mathrm{O}$ & $\mathrm{C}, 65.89 ; \mathrm{H}, 6.69 ; \mathrm{N}, 9.92$ & $\mathrm{C}, 65.82 ; \mathrm{H}, 6.39 ; \mathrm{N}, 9.75$ \\
\hline $4 b$ & $\mathrm{C}_{32} \mathrm{H}_{36} \mathrm{~N}_{4} \mathrm{OClF}_{3}$ & $\mathrm{C}, 65.69 ; \mathrm{H}, 6.20 ; \mathrm{N}, 9.58$ & $\mathrm{C}, 65.37 ; \mathrm{H}, 6.11 ; \mathrm{N}, 9.47$ \\
\hline $5 \mathrm{~b}$ & $\mathrm{C}_{27} \mathrm{H}_{25} \mathrm{~N}_{3} \mathrm{OClF}_{3} \cdot 0.25 \mathrm{H}_{2} \mathrm{O}$ & $\mathrm{C}, 64.29 ; \mathrm{H}, 5.09 ; \mathrm{N}, 8.33$ & $\mathrm{C}, 64.21 ; \mathrm{H}, 4.92 ; \mathrm{N}, 8.24$ \\
\hline $11 \mathrm{a}$ & $\mathrm{C}_{21} \mathrm{H}_{14} \mathrm{~N}_{2} \mathrm{OCl}_{2} \cdot 0.4 \mathrm{H}_{2} \mathrm{O}$ & $\mathrm{C}, 64.93 ; \mathrm{H}, 3.84 ; \mathrm{N}, 7.21$ & $\mathrm{C}, 64.94 ; \mathrm{H}, 3.49 ; \mathrm{N}, 7.13$ \\
\hline $11 \mathrm{~b}$ & $\mathrm{C}_{22} \mathrm{H}_{14} \mathrm{~N}_{2} \mathrm{OClF}_{3} \cdot 0.9 \mathrm{H}_{2} \mathrm{O}$ & $\mathrm{C}, 61.31 ; \mathrm{H}, 3.69 ; \mathrm{N}, 6.50$ & $\mathrm{C}, 61.31 ; \mathrm{H}, 3.49 ; \mathrm{N}, 6.46$ \\
\hline 12 & $\mathrm{C}_{21} \mathrm{H}_{14} \mathrm{~N}_{2} \mathrm{O}_{2} \mathrm{Cl}_{2} \cdot 0.3 \mathrm{H}_{2} \mathrm{O}$ & $\mathrm{C}, 62.64 ; \mathrm{H}, 3.65 ; \mathrm{N}, 6.96$ & $\mathrm{C}, 62.71 ; \mathrm{H}, 3.58 ; \mathrm{N}, 7.04$ \\
\hline 13 & $\mathrm{C}_{26} \mathrm{H}_{25} \mathrm{~N}_{3} \mathrm{O}_{2} \mathrm{Cl}_{2} \cdot \mathrm{H}_{2} \mathrm{O}$ & $\mathrm{C}, 62.40 ; \mathrm{H}, 5.44 ; \mathrm{N}, 8.40$ & $\mathrm{C}, 62.40 ; \mathrm{H}, 5.40 ; \mathrm{N}, 8.24$ \\
\hline 14 & $\mathrm{C}_{31} \mathrm{H}_{36} \mathrm{~N}_{4} \mathrm{O}_{2} \mathrm{Cl}_{2} \cdot 0.3 \mathrm{H}_{2} \mathrm{O}$ & $\mathrm{C}, 65.28 ; \mathrm{H}, 6.55 ; \mathrm{N}, 9.64$ & $\mathrm{C}, 65.03 ; \mathrm{H}, 6.51 ; \mathrm{N}, 9.52$ \\
\hline
\end{tabular}

